\title{
Composition and Diversity Variation of Avifauna, along Different Vegetative Habitat Types in a Human-Modified Area, University of Kelaniya, Sri Lanka
}

\author{
B. K. A. Bellanthudawa $(\mathbb{D}$, N. M. S. K. Nawalage, S. Subanky, P. A. B. G. Panagoda, \\ H. W. G. A. S. Weerasinghe, L. K. D. N. Tharaka, H. M. A. K. Handapangoda, \\ H. K. A. D. Silva, D. M. S. N. Dissanayake, and M. S. J. Abeywickrama \\ Department of Zoology and Environmental Management, Faculty of Science, University of Kelaniya, Sri Lanka
}

Correspondence should be addressed to B. K. A. Bellanthudawa; aravindabellanthudawa@gmail.com

Received 23 February 2019; Accepted 16 May 2019; Published 10 July 2019

Academic Editor: Marco Cucco

Copyright (c) 2019 B. K. A. Bellanthudawa et al. This is an open access article distributed under the Creative Commons Attribution License, which permits unrestricted use, distribution, and reproduction in any medium, provided the original work is properly cited.

\begin{abstract}
Role of conservation of birds has been least considered during modification of vegetative habitats, in studies conducted on birds in protected areas and urban landscapes in Sri Lanka. The present study was intended to assess the relationship between landscape and the composition and distribution of avifauna in University of Kelaniya, a human-modified area. The study was conducted selecting 8 habitats including open ground, low, moderately, and highly wooded habitats. A survey was conducted from 0530 to $0730 \mathrm{hr}$ in the morning and 1630-1830 hr in the evening from August to December 2016 ensuring eight sampling events at each habitat. Point counting method (15 m radius) was used along a $100 \mathrm{~m}$ line transect. Species diversity parameters were analyzed. Principal Component Analysis (PCA) was performed to characterize the habitats with bird species. A total of 40 species were recorded. Species richness $(\mathrm{r}=27)$ and species heterogeneity $\left(\mathrm{H}^{\prime}=3.09\right)$ were the highest in Mee amba sevana habitat while species evenness $(J=0.977)$ was the highest in medical center area habitat. Total abundance $(n=135)$ was recorded in Saiba ground. Asian brown flycatcher (Saiba ground, medical center area, Mee amba sevana, Girls' Hostel complex, and English language unit habitats) and white-bellied drongo (Saiba ground, medical center area, Girls' Hostel complex, English language unit, and Thal weta premises) were widely distributed ( $\mathrm{z}>0$, Kruskal-Wallis, Minitab 14). The second largest distribution was recorded by black-hooded oriole, bluetailed bee-eater, cattle egret, feral pigeon, brown-headed barbet, red-vented bulbul, and rose-ringed parakeet within four habitats ( $z>0$, Kruskal-Wallis). According to the PCA, Saiba ground habitat was categorized by open ground dwelling birds, and Mee amba sevana was characterized by frugivorous birds, while Girls' Hostel complex habitat was characterized by carnivorous birds. Comparatively, medical center area habitat contributes to the highest species diversity with many flowering and fruiting trees while providing sufficient food resources and high floral structural complexity. Recorded avifaunal community composition ensures considerable conservation value to university premises of Kelaniya. Awareness and monitoring programs are recommended for sustainable conservation of bird species in Kelaniya.
\end{abstract}

\section{Introduction}

Avifaunal assemblages have contributed significantly to the advancement of science in the field of community ecology. Comparative avifaunal diversity is an excellent indicator of ecosystem stability because birds respond quickly to changes in their environments [1]. Among all other species, birds play a major role in attracting human attention. In ecology, birds are of significance as pollinators and help in seed dispersal [2]. Furthermore, birds are relatively easy to observe and monitor. The concept of "using birds as indicators for recognizing land ecosystems rich in biological diversity" has now gained a wide global acceptance [3-6]. As ecosystems are degraded by anthropogenic activities, the need to monitor, evaluate, manage, and remediate ecological change will grow immensely. Because of the complexity of ecosystems, it is likely that the use of biological indicators may also similarly increase [7]. Avifaunal species community in an environment 
is subject to regular and irregular fluctuations, and bird populations respond to these changes in predictable ways. Their responding ability varies with scale of magnitude and degree to which they face that impact. The effects of environmental changes on bird populations are more often influenced by several intermediate factors, or the population changes are caused by numerous interacting effects [8]. The effective and direct responses are behavioral and physiological involving changes of individuals. These impacts influence the birth rate, death rate, and rate of distribution. Thereby these changes cause impacts on density, abundance, occurrence, size, geographic range, habitat occupancy, age structure, sex ratios, or the proportion of birds that breed [8]. Therefore, along with some parameters, abundance and diversity of avifaunal species serve as ecological health indicators.

Birds remaining in relatively natural fragmented habitats are affected by those communities and human activities associated with urbanization [9]. Rapid and unplanned urbanization often results in homogenous, dense, artificial environments which are dominated by many exotic communities of fauna [10]. However, the massive and vast conversion of forests into agricultural lands and urban lands has rapidly increased as a result of "development" [11, 12]. Some recent studies showed that heavy and wide spread of deforestation has led to declining and narrowing the birds' populations and diversity over range of landscapes $[13,14]$. Besides, urban development scenarios such as roads and highways have caused a significant impact on the bird assemblages [15]. In some birds' surveys, studies have shown that abundance, occurrence, and species richness of breeding birds are heavily impacted near roads, with larger declines near high-traffic roads than near lower traffic roads [16-18]. Noise pollution is one of critical factor that contributes to reduction in bird diversity and abundance especially in human-modified land uses. Even though sounds are closely linked with avian communities because these comprise a contribution towards species that rely on acoustic signals for mating, predator evasion, and other activities, limited numbers of studies have been conducted to assess its correlation. Findings of [19] stated that male Willow Warblers experienced difficulties in females' attraction along with highways, as it masks male song by noise as a possible mechanism. Nevertheless, some studies claim that disturbance of vocal communication does not cause reduced densities of birds. Presently, correlation between bird communities and the habitat variables has become a theme in ecological studies [20]. Conversely, those studies were conducted in tropics confined to examine the effect on birds in urban-rural gradients $[13,21,22]$ and agricultural ecosystems $[23,24]$. In the available literature, the contribution and extent of focus on avifaunal distribution patterns in natural ecosystems are limited. The insufficiency of proper studies prior to phases of the destruction and threats exerted on natural forest habitats changes the focus of the attention of conservation planners from natural forest patches in early phases of destruction to severely destructed habitats and their regeneration. Vegetation cover and availability of open space of the habitat are rapidly changing with the anthropogenic disturbance.
Since there is a positive correlation between availability of vegetation cover and birds' biodiversity [23], continuous monitoring of the landscape changes is an ideal tool to predict community structure of fauna associated with the habitat.

The geographical location of Sri Lanka encounters high degree of biodiversity. Sri Lanka is a tropical island in the Indian Ocean, at the southern point of the Indian subcontinent, with a main island and several small islands. Furthermore, Sri Lanka is placed among the 36 biodiversity hotspots in the world [25]. Therefore, Sri Lanka is considered as the highest in Asia with respect to 'biodiversity per unit area' [26]. Study conducted by [27] stated that currently Sri Lanka is enriched with 453 avifaunal species including 240 species of breeding residents, of which 27 are endemics. According to [28], there are different six avifaunal zones, based on the distribution patterns of the resident bird species, namely, northern or Indian zone, low country wet zone, mid-country wet zone, hill country wet zone, dry zone, and Uva zone. Among all zones, hill country wet zone holds higher percentage of the endemic and threatened species $[28,29]$. In Sri Lanka context, avifaunal species are facing severe threats due to deforestation, urban developments, and highway improvements. As a result, the forest area coverage in Sri Lanka (33.0\% in 2015) is rapidly declining [30]. Even though several studies have been conducted on birds in and around protected areas in Sri Lanka, the role of humanmodified land uses in conservation of birds has been greatly neglected.

Hence, the objective of the present study was to create a baseline species checklist of birds in the university premises for ensuring the sustainable avifaunal conservation and management efforts. Further, this birds survey aimed to focus on the dispersal of habitat specific birds species along various human-modified land uses. Additionally, this study focused on assessing the variation of species composition and diversity parameters with change of vegetation cover humanmodified habitats.

\section{Materials and Methods}

2.1. Study Area and Site Selection. The study area is located in University of Kelaniya, Dalugama, Gampaha district, comprised of 18.7 ha in wet zone of Sri Lanka (Figure 1). The bird survey was conducted within university premises of Kelaniya by selecting eight habitats using purposive/judgmental sampling covering whole study area while representing different habitats types such as open grounds, low wooded, moderately wooded, and highly wooded with more or less human disturbances (Table 1: habitat classification). Digitizing technique in Arc GIS 10.2 version was used for calculation of percentage of canopy cover in each habitat [31].

\section{Percentage canopy cover}

$$
=\frac{\text { Area of greenish color within the selected site }}{\text { Total area of the Selected site }}
$$




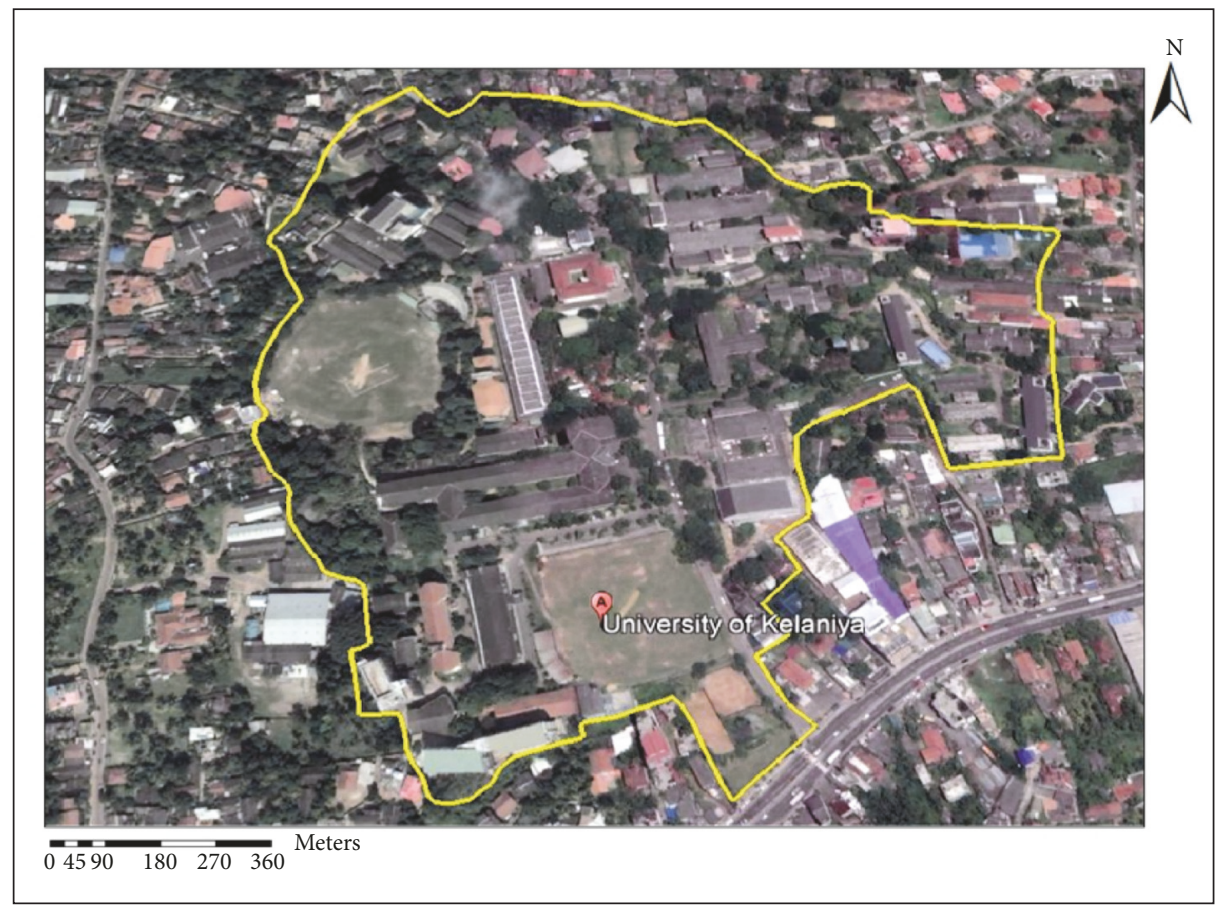

FIgURE 1: The study area of University of Kelaniya.

TABLE 1: Habitat categorization depending on the nature and percentage of tree cover of the environment.

\begin{tabular}{|c|c|c|c|}
\hline Habitat Number $(\mathrm{H})$ & Common name of the habitat & $\begin{array}{l}\text { Percentage of cover of the wooded } \\
\text { vegetation }(\%)\end{array}$ & Type of the habitat \\
\hline H 1 & Saiba ground (SG) & 1.7 & open ground \\
\hline $\mathrm{H} 2$ & Gym canteen premises (GCP) & 21.7 & Low wooded \\
\hline H 3 & Medical centre area (MCA) & 63.9 & Highly wooded \\
\hline H 4 & Mee amba sevana (MAS) & 91.4 & Highly wooded \\
\hline H 5 & Girls' hostel complex (GHC) & 27.3 & Low wooded \\
\hline H 6 & $\begin{array}{c}\text { Management and IT department } \\
\text { premises (MIT) }\end{array}$ & 36.4 & Moderately wooded \\
\hline H 7 & $\begin{array}{l}\text { English language training unit premises } \\
\text { (ELTU) }\end{array}$ & 55.3 & Moderately wooded \\
\hline H 8 & Thal weta premises (TWP) & 26.8 & Low wooded \\
\hline
\end{tabular}

Note: The percentage of wood cover was calculated, area of canopy cover of habitat with reference to total area of the habitat.

Site categorization was based on the percentage cover of the vegetation of the habitats. Habitat $1 / \mathrm{H}$ 1/Saiba ground (SG) is the one open ground with short grass species.

Grass species such as Thuththiri (Chrysopogon aciculatus), Bala thana (Eleusine indica), Mottu thana (Cyperus kyllingia), and Nidikumba (Mimosa pudica) were dominated in the open ground habitat. A large part of the Saiba ground habitat is composed of open area with dead leaves and soil, and east to southwest margin of the habitat is surrounded by wooded line. The level of disturbance in Saiba ground is high as it is used as a playground by undergraduates of the University of Kelaniya. Habitats 2, 5, and 8, respectively, standing for gym canteen premises (GCP), Girls' Hostel complex (GHC), and Thal weta premises (TWP), are grouped under the low wooded habitats covering $21.7 \%$ to $27.3 \%$ of vegetation cover.
A few number of palm trees (Arecaceae spp.) and Temple trees (Plumeria spp.) were present. These areas are comprised of some built-up and open spacious locations with a smaller number of trees. In the category of moderately wooded type habitats, Management and IT department premises (MIT) and English language training unit premises (ELTU) were the habitats denoted as $\mathrm{H} 6$ and $\mathrm{H} 7$, respectively. The wooded plantation cover ranges from $36 \%$ to $56 \%$ hosting Neem (Azadirachta spp.), Mango (Mangifera indica), Cashew (Anacardium occidentale), Jackfruit (Artocarpus heterophyllus), and Kottamba (Terminalia catappa). Habitat $3(\mathrm{H} 3)$ and Habitat 4 (H 4), namely, medical center area (MCA) and Mee amba sevana (MAS), were grouped under the highly wooded habitats. The H 3 and $\mathrm{H} 4$ cover $63.9 \%$ and $91.4 \%$ of the wooded vegetation with reference to the area of the habitat 
correspondingly. Mango (Mangifera indica), Kottamba (Terminalia catappa), Mara (Samanea saman), Avocado (Persea americana), Jackfruit (Artocarpus heterophyllus), Mahogany (Swietenia macrophylla), and Asoka (Saraca asoca) dominate in those two habitats with high percentage of fruiting plants.

2.2. Sampling Procedure. The field survey was conducted during the period of $0530 \mathrm{hr}-0730 \mathrm{hr}$ in the morning and $1630 \mathrm{hr}-$ $1830 \mathrm{hr}$ in the evening time of August 2016 to December 2016. Eight sampling events $(n=8)$ were conducted at each habitat covering 64 sampling events throughout the study period. Point counting method ( $15 \mathrm{~m}$ radius) was used for sampling technique $[10,32]$ along a $100 \mathrm{~m}$ line transect. In a single habitat, 3 points were selected along a $100 \mathrm{~m}$ line transect in a sampling event. 20 minutes were spent at each point along $100 \mathrm{~m}$ line transect for observations. 60 -minute $(20 * 3)$ sampling duration was observed in a particular sampling habitat along $100 \mathrm{~m}$ line transect. Survey was not conducted during rainy and windy weather. Visual assessment (seeing) and birds' calls were considered to record number of birds in each species. Opticron $8 \times 30$, Super Zenith $8 \times 40$, binoculars, and standard guide of [33] were used to identify species.

A baseline of bird database (checklist) was prepared considering all the recorded species during the study period. Species diversity parameters such as total abundance, species richness, species heterogeneity using Shannon-Weiner diversity index $\left(\mathrm{H}^{\prime}\right)$, and species evenness using Pielou's evenness index $(\mathrm{J})$ were calculated using Microsoft Excel 2013.

Abundance. Abundance of species in a community of sample is the number of individuals belonging to that species [34].

\section{Abundance \\ $=$ Total number of individuals belong to particular species}

Species Richness. Species richness is the total number of species in an assemblage or a sample [34].

\section{Species richness}

$=$ Total number of species in an assemblage or a sample

Shannon-Wiener Diversity Index $\left(H^{\prime}\right)$. Shannon-Wiener diversity index $(\mathrm{H})$ is commonly used to calculate aquatic and terrestrial biodiversity. This index was calculated as

$$
H^{\prime}=\sum_{i=1}^{s}\{(P i) \times(\ln P i)\}
$$

where $\mathrm{pi}$ is the proportion of individuals in the " $\mathrm{i}$ " " taxon of the community and $s$ is the total number of taxa in the community.

As the number and distribution of taxa (biotic diversity) within the community increase, so does the value of " $\mathrm{H}$ " [34].

Pielou's Evenness Index ( $J$ ). The distribution of individuals of a species is the evenness. It makes sense to consider species

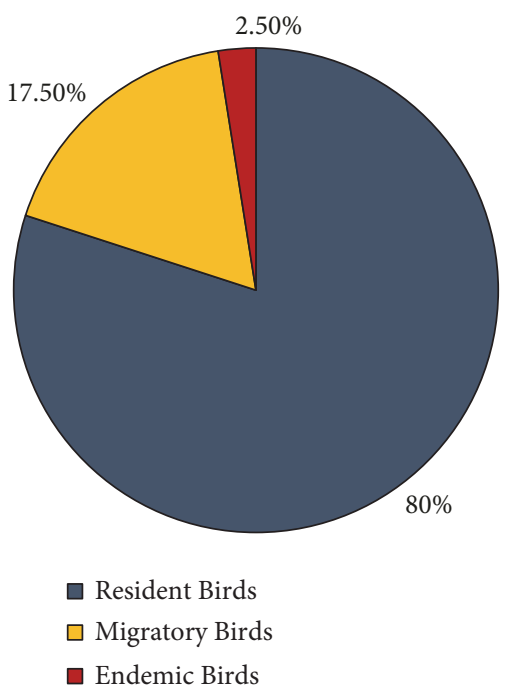

FIgure 2: Percentage of resident, migratory, and endemic birds recorded in the survey.

richness and species evenness as two independent characteristics of biological communities that together constitute its diversity [35].

$$
\text { Pielou's Evenness Index }(J)=\frac{H^{\prime}}{\log S}
$$

where $\mathrm{H}^{\prime}$ is the Shannon-Wiener diversity index and $\mathrm{S}$ is the number of species in the community.

Species distribution among habitats was analyzed using Kruskal-Wallis test (Minitab 14 software) after confirming the normal distribution. Principal Component Analysis (PCA) was followed to characterize the habitats with abundance of representative bird species using Minitab 14 software.

\section{Results}

3.1. Baseline Database (Checklist) of Birds Recorded throughout the Study of University of Kelaniya. Total species of birds recorded during the birds' survey is shown in Table 2. As per Table 2, one species representing order Apodiformes, order Accipitriformes, order Psittaciformes, and order Pelecaniformes, two species representing order Cuculiformes and order Coraciiformes, 3 species representing order Piciformes and order Columbiformes, and 26 species representing order Passeriformes were observed in the survey. The most dominant order was "Passeriformes". In summary, a total of 40 avifaunal species were recorded. The International Union for Conservation of Nature (IUCN) conservation status (2012) of the birds in the study area is encountered and categorized under Least Concern (LC) stage. This implied that most of threatened and endangered bird species are not found in the University of Kelaniya at current condition.

3.2. The Species Composition and Diversity of Bird Species in Habitats. The habitat dispersal status of birds is also represented in Figure 2. The percentage of resident birds was 


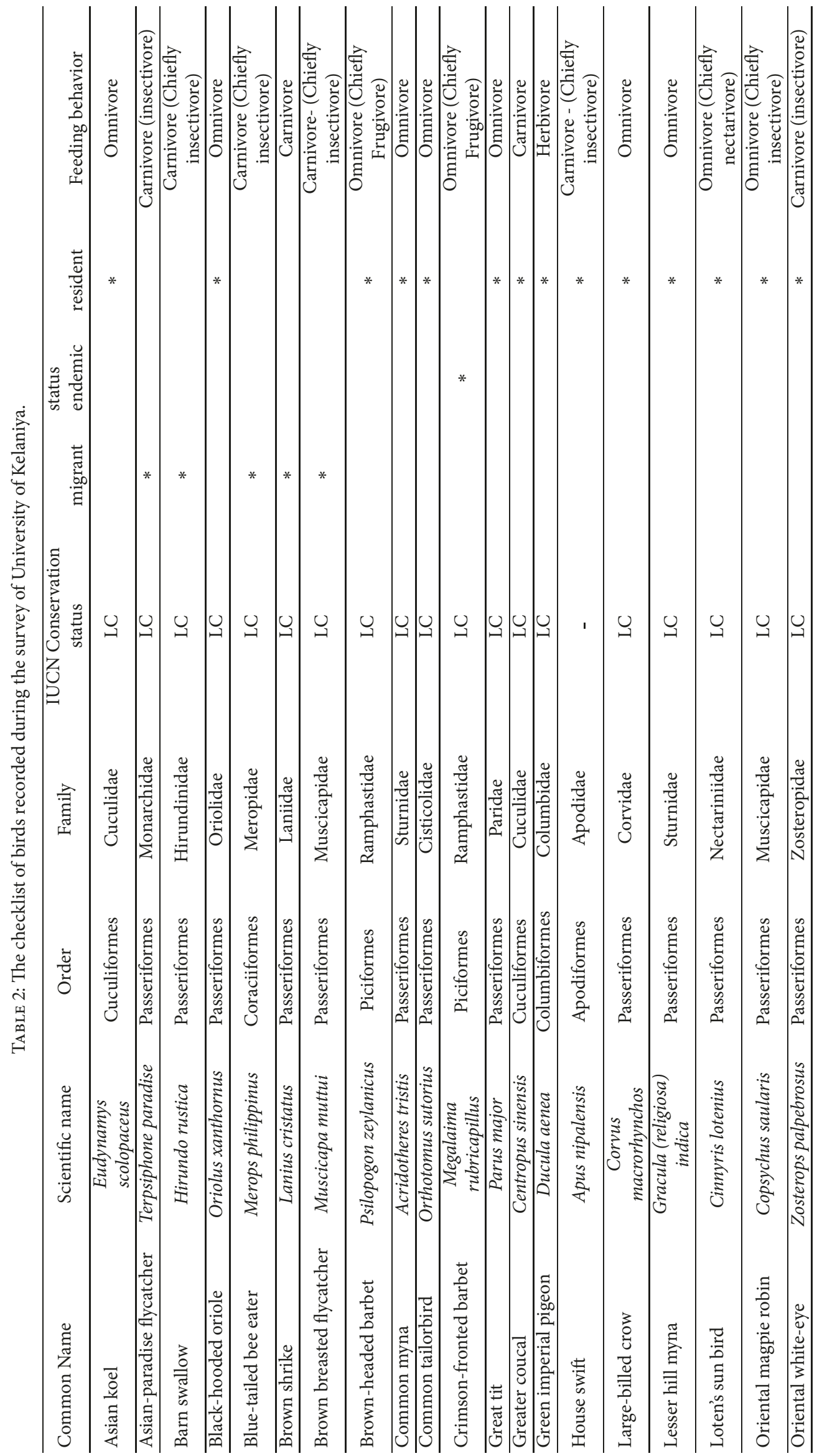




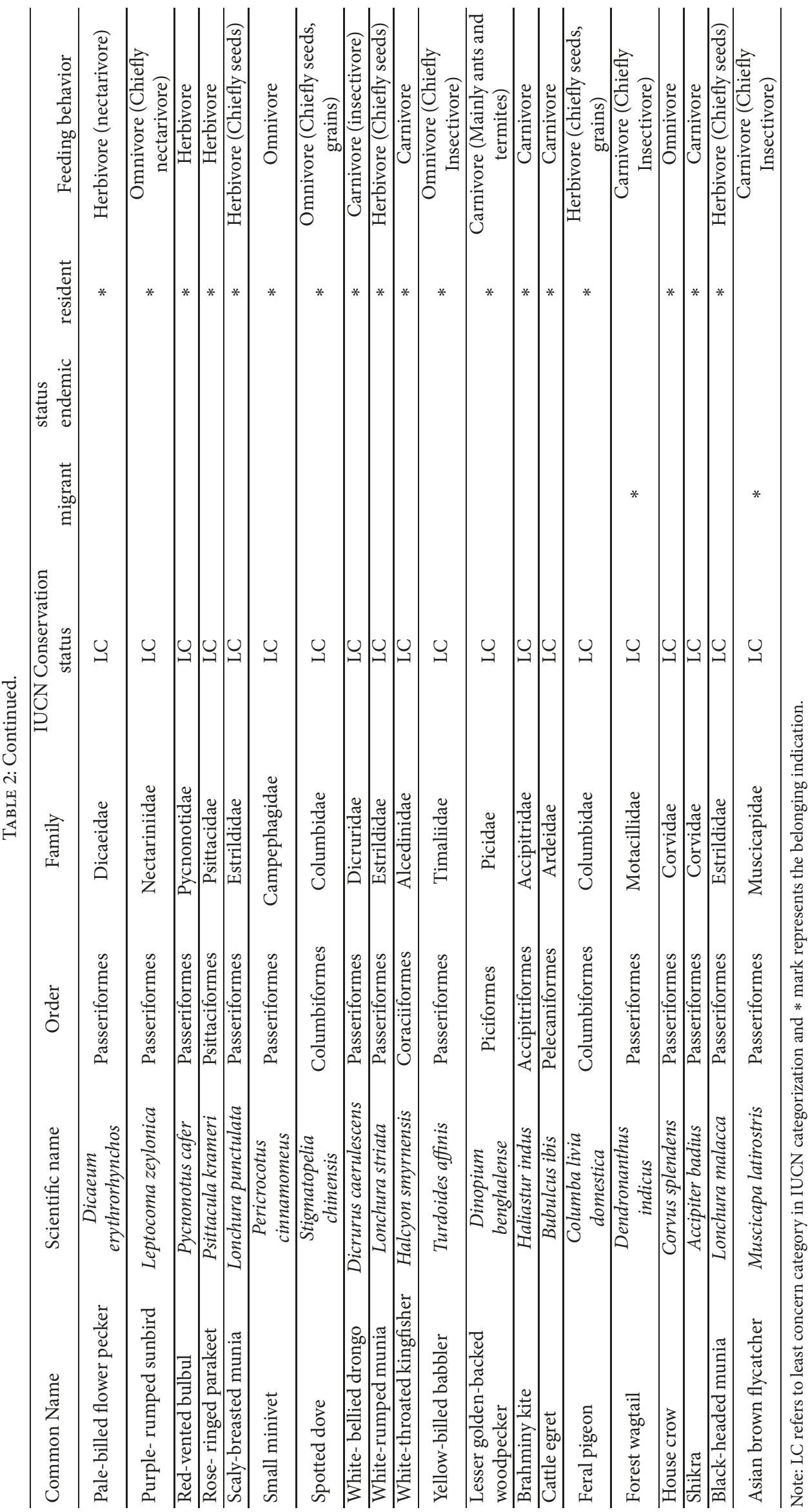




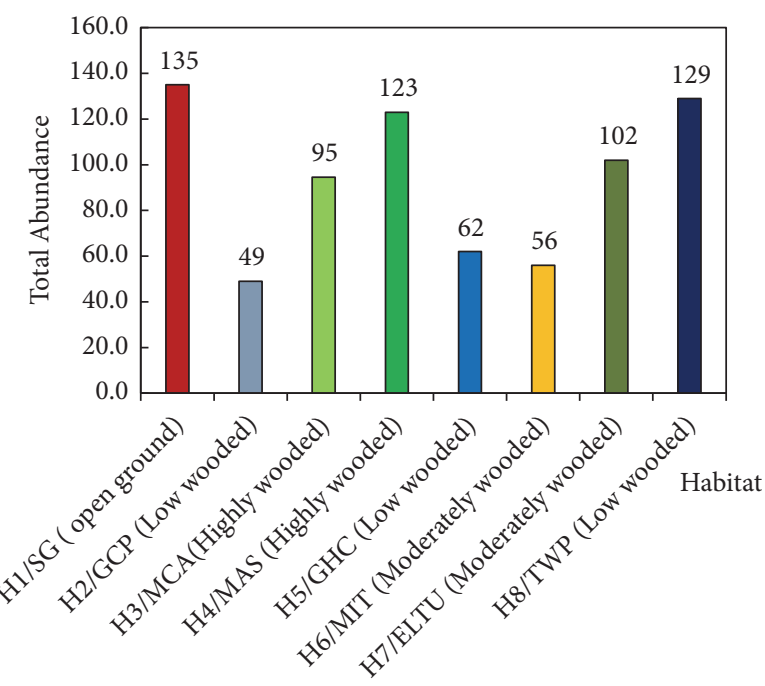

FIGURE 3: Variation of total abundance of species between different habitats.

significantly high (80\%) compared to the total number of bird species. According to Figure 2, percentages of migrant birds and endemic birds were recorded as $17.5 \%$ and $2.5 \%$, respectively. Findings indicated that majority of the residential bird species have occupied the habitats during sampling period compared to the migrant and endemic bird species in the University of Kelaniya premises.

Diversity and species composition parameters showed a considerable variation among different habitats selected. The mean abundance and total maximum abundance of birds (in one sampling event) are given in Figure 3 which illustrates that highest abundance (135 individuals) was recorded in Saiba ground habitat which is an open grassland habitat. The second highest total abundance was shown from Mee amba sevana habitat (highly wooded) and Thal weta premises (low wooded) habitats. Further, gym canteen premises habitat was the least birds' abundant habitat among 4 types of habitats. Generally, findings showed that there are significant higher numbers of birds in highly wooded and open space habitats compared to other habitats. Species richness provided information of the diverse nature of the habitats. Figure 4 shows that Mee amba sevana habitat (highly wooded), Saiba ground habitat (open ground), and English language teaching unit habitat (moderately wooded), respectively, indicated higher species richness values of 27,24 , and 23 . In contrast, gym canteen premises habitat (Low wooded) and English language teaching unit habitat (moderately wooded) indicated the lowest species richness as 14. In assessing the differences of the Shannon-Weiner diversity index $\left(\mathrm{H}^{\prime}\right)$ among habitats, Mee amba sevana and Saiba ground expressed the highest Shannon-Weiner diversity index $\left(\mathrm{H}^{\prime}=3.09\right.$ and $\left.\mathrm{H}^{\prime}=2.93\right)$ correspondingly. Moreover, gym canteen premises were the lowest heterogeneous habitat with regard to Shannon-Weiner diversity index. Inclusively, Shannon-Weiner diversity index value varied in the range of 2.5-3.1 reflecting that all sites seem comparatively heterogeneous (Figure 5 ). In terms of even dispersal and distribution of species between sampling

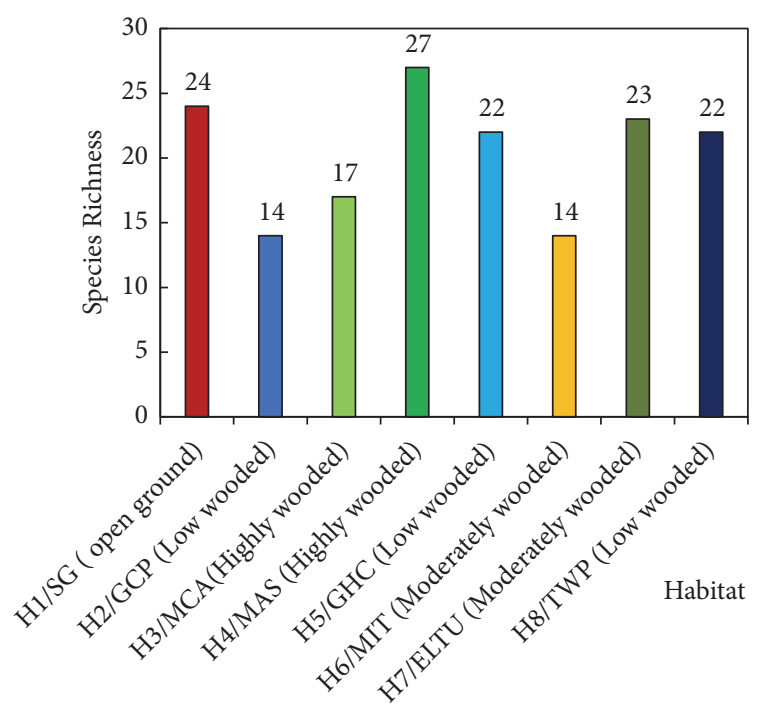

FIGURE 4: Variation of species richness among habitats.

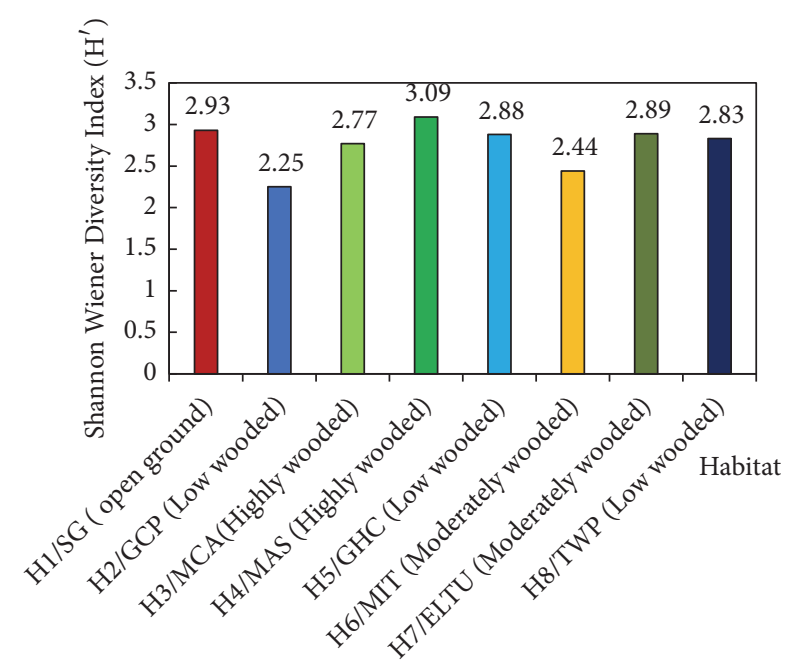

FIGURE 5: Variation of Shannon-Wiener diversity index (H') in habitats.

habitats, medical center area, Mee amba sevana, and Girls' Hostel complex premises showed the most evenly distributed habitats numerically $(J=0.977, J=0.937$, and $J=0.932$ orderly). Gym canteen premises were the lowest evenly dispersed habitat $(J=0.85)$ during the survey. Comprehensively, majority of sampled habitats were evenly distributed with reference to species (Figure 6 ).

As per the Kruskal-Wallis statistical results for species distribution (Table 3 ), Asian-paradise flycatcher, black-rumped flameback, cattle egret, feral pigeon, house crow, palebilled flowerpecker, small minivet, and white-rumped munia species were not significantly different in all the habitat types ( $p>0.05$, Kruskal-Wallis). The Asian brown flycatcher (Saiba ground, medical center area, Mee amba sevana, Girls' Hostel complex, and English language teaching unit habitats) and white-bellied drongo (Saiba ground, Mee amba sevana, Girls' Hostel complex, English language teaching 


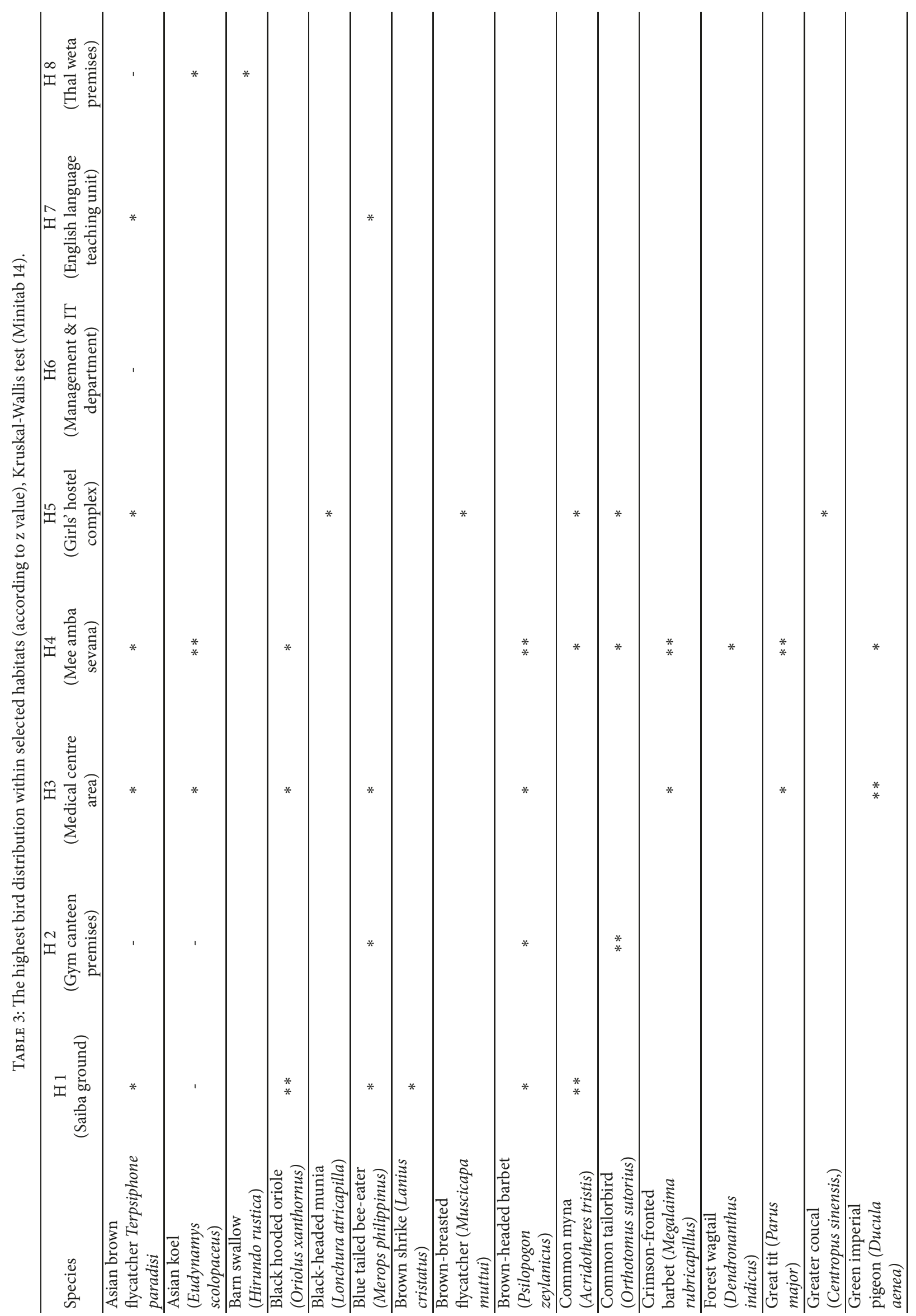




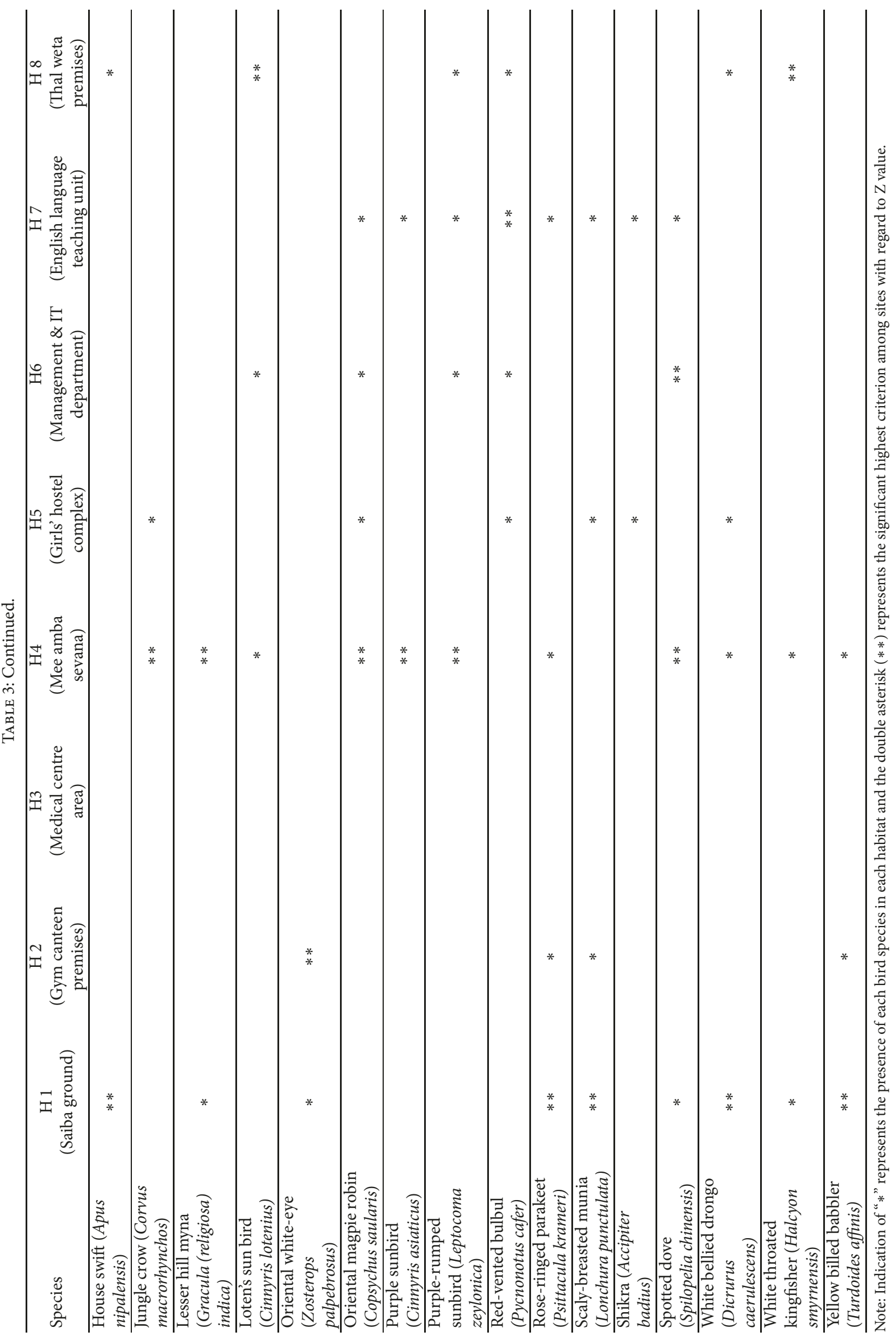




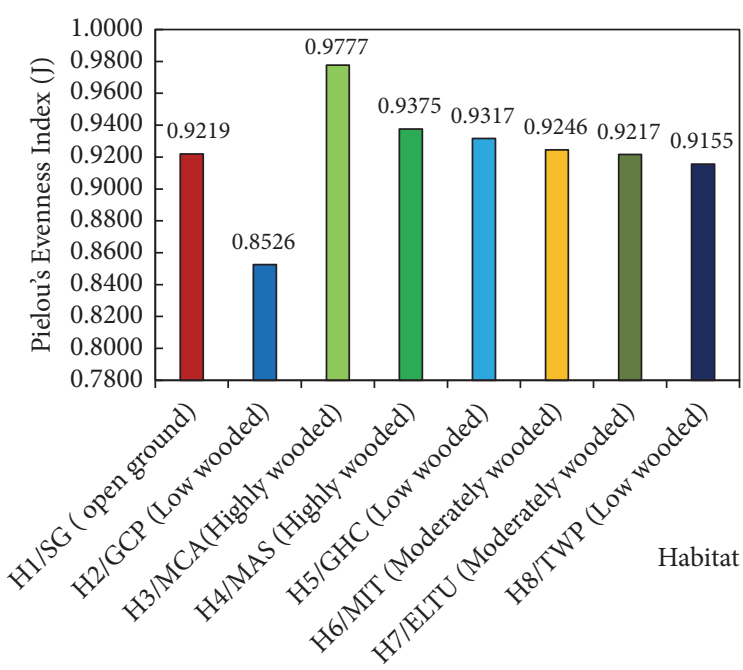

FIgURE 6: Variation of Pielou's evenness index (J) among habitats.

unit, and Thal weta premises habitats) were recorded as widely distributed within five habitats out of selected eight habitats. The second largest distribution was recorded by black-hooded oriole, blue-tailed bee-eater, cattle egret, feral pigeon, brown-headed barbet, oriental magpie robin, purplerumped sunbird, red-vented bulbul, rose-ringed parakeet, and scaly-breasted munia within four habitats out of eight selected habitats. The third most distribution was recorded within three habitats out of eight habitats by Asian koel, common myna, common tailor bird, Loren's sunbird, and white-throated kingfisher. Other observed bird species were barn swallow, black-headed munia, brown shrike, brownbreasted flycatcher, forest wagtail, greater coucal, green imperial pigeon, house swift, jungle crow, lesser hill myna, oriental white eye, purple sun bird, shikra, and yellow-billed babbler $(\mathrm{z}>0$, Kruskal-Wallis, Minitab 14).

Ordination of the habitats based on $\mathrm{PCl}$ and PC2 scores of Principal Component Analysis of the abundance of avifauna of sampling habitats is given in Figure 7. The eigenvalues of the first two principal components (PC 1 and PC 2), eigenvectors of the bird species variables, and the principal component scores for different habitats are given in Table 4 . Cumulatively, $67 \%$ of the total variation of abundance of birds among habitats is represented by PC 1 and PC 2. According to the PCA, habitats were characterized as follows based on distribution avifaunal species in study area.

Four main contrasting groups were generated comprising a category of open space ground, combination of moderately wooded (Management and IT and English language teaching unit) and low wooded habitats (gym canteen premises and Girls' Hostel complex), medical center area, highly wooded Mee amba sevana, and Thal weta premises (low wooded), separately (Figure 7). Saiba ground (open ground) was characterized by Asian-paradise flycatcher, brown shrike, and house swift. Girls' Hostel complex habitat (low wooded) was characterized by rose-ringed parakeet whereas cattle egret, black-headed munia, shikra, greater coucal, house crow, and brown-breasted flycatcher were identical in Girls' Hostel complex habitat which stands as a low wooded habitat. Moreover, Thal weta premises housed birds such as barn swallow, black-hooded oriole, and white-throated kingfisher. In the group of moderately wooded habitats, red-vented bulbul was the characteristic bird in Management and IT department habitat while English language teaching unit habitats was represented by shikra, yellow-billed babbler, barn swallow, black-headed oriole, and greater coucal. Medical center area habitat which is highly wooded was characterized by feral pigeon. Further, highly wooded Mee amba sevana habitat was characterized by species like brahminy kite, crimson-fronted barbet, forest wagtail, lesser hill myna, brown-headed barbet, and small minivet. According to the PCA habitat categorization considering PC score 1 to PC score 4, Saiba ground was categorized by open grassland birds. Similarly, Mee amba sevana was characterized by frugivorous birds while Girls' Hostel complex habitat was dominated by carnivorous birds which can easily find their food items in that environment.

\section{Discussion}

Complexity and the nature of habitats and micro habitats constitute a valuable factor that determines the species composition and diversity in a particular area. Thereby several bird species tend to find their own suitable habitats where they have access and resources to feed and breed. Highly complex habitats provide wide array of opportunities to higher number of bird species as they are enriched with wide range of foods and other resources to sustain lives. This parameter governs the variation of avifaunal species composition and diversity in large scale. Parameters such as abundance and relative abundance of bird species might be associated with nature of habitat, abundance of food, and breeding season of the species [2]. During the bird survey, highest birds' abundance, richness, evenness, and diversity were recorded mainly in highly wooded habitats and one moderately wooded habitat. Habitat $4 /$ Mee amba sevana habitat showed 123 individuals (Figure 3) of birds from different 27 species (Figure 3) throughout the sampling period. As Mee amba sevana habitat is composed of Mango (Mangifera indica), Kumbuk (Terminalia arjuna), Kottamba (Terminalia catappa), Mara (Samanea saman), Avocado (Persea americana), Jackfruit (Artocarpus heterophyllus), Mahogany (Swietenia macrophylla), Asoka (Saraca asoca), and some fruiting plants, they facilitate higher canopy variation and structural variation among those wooded and nonwooded floral species. It may enable most of bird species to forage, rest, and feed on different plant species. The role of diversity of foliage height and horizontal habitat variety influences the species richness in a particular habitat or a microhabitat in vegetative environment $[36,37]$. Density and lushness of vegetation cover in those highly wooded areas enhance formation of favorable micro climate in those habitats. Among habitats, highly wooded and moderately wooded areas such as Mee amba sevana habitats, medical center area, and English language teaching unit habitat hold high degree of species richness. Woody habitats with wellstructured and heterogeneous plant species, including woody 


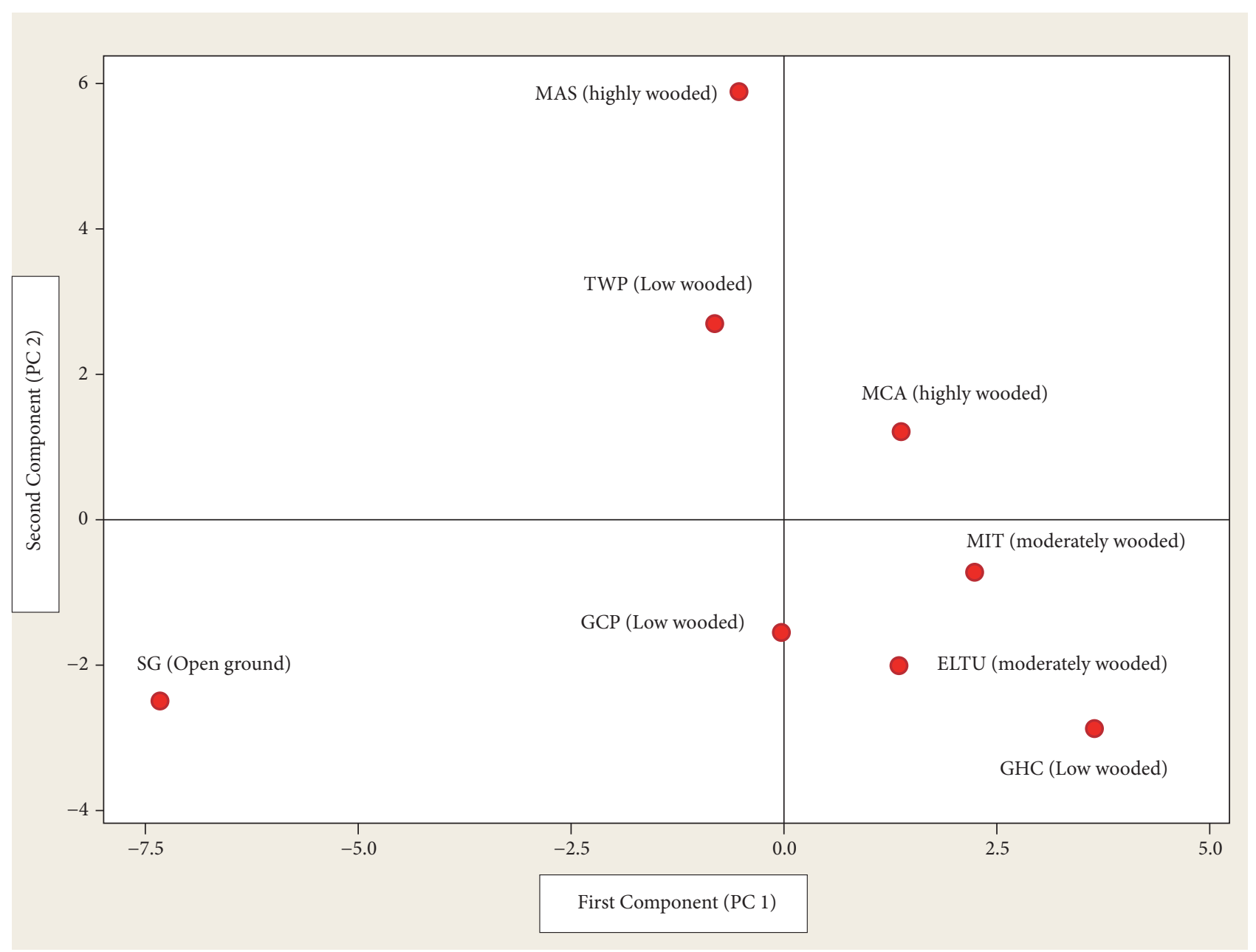

Figure 7: Ordination of the habitats based on PC1 and PC2 scores of Principal Component Analysis of the abundance of avifauna of sampling habitats.

lianas and grasses, provided more niches and food sources for birds [38]. Generally, wooded plant cover shows the value of niches and floristic aspects for abundance of most bird species [38]. The mainly forested birds species have a positive relationship with canopy cover, ground tree density, and tree density. Presence of more trees provides various food sources or nesting or perching grounds for the survival of birds [39]. Thus, different plant species maximize the choices of food and nutrition requirement which most frugivorous and plant feeding animals depend upon. Some environmental parameters such as rainfall, mean temperature, solar radiation, and moisture content may be ideally maintained among those highly to moderately wooded canopies which strengthen the housing of different bird species. Climatic conditions like mean annual temperature, evapotranspiration, and solar radiation are responsible for predicting and supporting the changes in species richness of birds [40,41].

Conversely, a significant increase in total abundance and richness of birds in open ground area/Saiba ground and Thal weta premises (low wooded) was recorded during the sampling period compared to other moderately to low wooded habitats (Figures 3 and 4). This contradicts the idea that is given by [39], as it provides high degree of species richness and biodiversity when vegetation cover is denser. Further, anthropogenic influence and increased disturbances reduce the presence of birds as they avoid risks and tend to show avoidance behavior [42]. However, Saiba ground is structured with numerous micro habitats like dying branches with leaves, water pools, bank vegetation in the ground (very smaller coverage), grassland, and open ground (enriched with soil particles, debris, decaying plant leaves, soil animals like worms and oligochaetes, ground dwelling insects, and flies). Hence, wide varieties of micro habitats govern the habitation, foraging, nesting, and breeding birds in those premises. As their food resources are available on the habitat, more birds may be attracted to feed upon those in Saiba ground. Thal weta premises, which are also a low wooded environment, facilitate man-made structures such as buildings, an abandon pond, very few wooded trees and a few flowering plants, paved roads, and payments. Most of resting and perching birds were recorded around that location. Therefore, according to the observed results, another reason for high abundance of birds recorded in open ground/Saiba ground may be the lower level of competition among residential birds 
TABLE 4: Final output of the PCA of abundance of birds' species recorded in different habitat types in University of Kelaniya. Cumulative \% variations of only the $\mathrm{PC} 1$ and $\mathrm{PC} 2$ are shown. A considerable cumulative percentage as $67 \%$ of the total variation among abundance of bird species is explained by $\mathrm{PC} 1$ and $\mathrm{PC} 2$ axis.

(a) Eigenvectors (coefficients in the linear combinations of variables making up PCs)

\begin{tabular}{|c|c|c|}
\hline Variable & $P C 1$ & PC2 \\
\hline Asian brown flycatcher & -0.061 & 0.121 \\
\hline Asian koel & -0.055 & 0.263 \\
\hline Asian paradise flycatcher & -0.162 & -0.058 \\
\hline Barn swallow & -0.029 & 0.118 \\
\hline Black hooded oriole & -0.281 & 0.01 \\
\hline Black-headed munia & 0.135 & -0.126 \\
\hline Black-rumped flame back & -0.268 & -0.088 \\
\hline Blue tailed bee-eater & -0.246 & -0.152 \\
\hline Brahminy kite & -0.018 & 0.257 \\
\hline Brown shrike & -0.27 & -0.11 \\
\hline Brown-breasted flycatcher & 0.135 & -0.126 \\
\hline Brown-headed barbet & -0.123 & 0.2 \\
\hline Cattle egret & 0.135 & -0.126 \\
\hline Common myna & -0.235 & -0.013 \\
\hline Common tailorbird & -0.069 & 0.185 \\
\hline Crimson-fronted barbet & -0.051 & 0.222 \\
\hline Feral pigeon & 0.139 & 0.05 \\
\hline Forest wagtail & -0.018 & 0.257 \\
\hline Great tit & 0.007 & 0.269 \\
\hline Greater coucal & 0.141 & -0.165 \\
\hline Green imperial pigeon & 0.071 & 0.071 \\
\hline House swift & -0.278 & -0.07 \\
\hline House crow & 0.165 & -0.183 \\
\hline Jungle crow & 0.06 & 0.17 \\
\hline Lesser hill myna & -0.221 & 0.112 \\
\hline Loten's sunbird & 0.012 & 0.227 \\
\hline Oriental white-eye & -0.267 & -0.08 \\
\hline Oriental magpie robin & 0.13 & 0.051 \\
\hline Pale-billed flower pecker & 0.013 & 0.22 \\
\hline Purple-rumped sunbird & 0.082 & 0.19 \\
\hline Red-vented bulbul & 0.12 & -0.078 \\
\hline Rose-ringed parakeet & -0.136 & -0.063 \\
\hline Scaly-breasted munia & -0.181 & -0.221 \\
\hline Shikra & 0.141 & -0.165 \\
\hline Small minivet & -0.018 & 0.257 \\
\hline white rumped munia & -0.252 & -0.048 \\
\hline Spotted dove & -0.167 & -0.164 \\
\hline White bellied drongo & -0.063 & -0.052 \\
\hline White throated kingfisher & -0.227 & 0.038 \\
\hline Yellow billed babbler & -0.136 & 0.187 \\
\hline
\end{tabular}

(b) Eigenvalues

\begin{tabular}{lccc}
\hline PC & Eigen values & \%Variation & Cumulative \% Variation \\
\hline 1 & 10.93 & 36 & 36 \\
2 & 9.19 & 31 & 67 \\
3 & 6.41 & 18.2 & 85.2 \\
4 & 4.47 & 10.8 & 95.2 \\
\hline
\end{tabular}


(c) Principal component scores

\begin{tabular}{|c|c|c|c|c|}
\hline Sample & SCORE 1 & SCORE 2 & SCORE 3 & SCORE 4 \\
\hline Saiba ground (Open ground) & -7.315 & -2.500 & 1.243 & -0.075 \\
\hline Gym canteen premises (Low wooded) & -0.030 & -1.555 & -2.884 & 0.030 \\
\hline Medical center area (Highly wooded) & 1.374 & 1.191 & -0.337 & 2.254 \\
\hline Mee amba sevana (Highly wooded) & -0.498 & 5.843 & 2.771 & 0.585 \\
\hline Girls' hostel complex (Low wooded) & 3.655 & -2.875 & 3.670 & -2.808 \\
\hline Management and IT premises (Moderately wooded) & 2.246 & -0.756 & -2.490 & 0.250 \\
\hline English language training unit (Moderately wooded) & 1.355 & -2.023 & 0.687 & 2.873 \\
\hline Thal weta premises (Low wooded) & -0.788 & 2.674 & -2.660 & -3.110 \\
\hline
\end{tabular}

due to resources partitioning. The linkage between occupying of suitable niche space and species richness supports the evidence to draw conclusion and predictions on variation of biodiversity [43]. In a given habitat, species richness is denoted by presence of range of resources, including finding of foods and mechanisms to avoid predators. These resources are partitioned in between species to weaken the competition raised among different species [44-46]. A research study [43] reported that resources in the core of particular habitat are highly rich and exploitable by generalists compared to peripheral resources. This might be a factor for having higher degree of biodiversity in both Saiba ground and Mee amba sevana.

Sampling habitats such as low wooded Girls' Hostel complex and moderately wooded Management and IT area indicated lower values for species richness, Shannon-Weiner diversity, and Pielou's evenness indices (Figures 4, 5, and 6). The main influential factor for this variation may be due to the location of these habitats neighboring paved roads where people and moving motor vehicles are available. In particular, these two habitats are highly occupied by residential undergraduates in the University of Kelaniya. Thus, it may generate a considerable magnitude of noise forcing avifaunal species to avoid foraging, resting, and habitation. Increased distance and traffic sounds from roads and highways, and anthropogenic disturbances negatively correlate with abundance and diversity of birds [47]. A study [48] supported this finding suggesting two main reasons. Firstly, communication of birds for maintenance and establishment of territories may be affected by huge noise. This may interfere with intrapair and adult-young communication as well. Moreover, human noise may confuse individuals, making them more vulnerable to predation. Also, this may increase antipredator attention, which could indirectly affect bird reproductive rate [48].

In terms of species composition and habitat dispersal status of birds in the total study area of University of Kelaniya, $80 \%$ of resident birds, $17.5 \%$ of migrants, and $2.5 \%$ of endemic birds were observed (Figure 2). The results of present study mentioned that endemism has been greatly affected by habitat alteration. As University of Kelaniya is located in an urban landscape, there is a higher possibility of encountering lower abundance of endemism among bird species. In general, community composition of birds in urban environment is represented by few migrant and insectivorous bird species while housing high omnivorous, resident, exotic, and granivorous bird species [49]. The development effects became relatively lower out of urban areas and became rapidly growing in urban and suburban areas [50,51]. There is high correlation between high pedestrian or urbanized habitats in wildlife refuges and lower species richness and abundance of endemic and migrant birds [52]. Besides, diversity aspects of migrant birds and insectivore birds also decline with higher percentage of the contiguous landscape covered by pavements, buildup areas coverage, and bare grounds [49]. Therefore, the present study findings are proven by the available literature.

Shannon-Weiner diversity index is a parameter used for comparing diversity between various habitats. It gives information on heterogeneity of habitat. It assumes that individuals are randomly selected and all the species are represented in the sample [53]. In addition, Pielou's evenness index, which provides indication regarding evenness of species in a habitat, indicated that two highly wooded habitats, namely, Mee aba sevana and medical center area, hold the highest evenness values compared to all other habitats (Figure 5). These results showed that higher wooded percentage accounts for higher degree of heterogeneity and evenness of habitats. Availability of numerous micro habitats on Mee amba sevana and medical center area habitats may be the effective reason of increased heterogeneity and evenness. The study of [54] supported the idea that vegetation cover is a major contributor for variation and change of species composition and diversity. Fluctuation of number of birds in a habitat connected with vegetation changes along some biological and environmental gradients.

PCA habitat categorization illustrated that Saiba ground was categorized by open grassland birds. Similarly, Mee aba sevana was characterized by frugivore birds while Girls' Hostel complex was dominated by carnivorous birds which can easily find their food items in that environment. Species like crimson-fronted barbet, forest wagtail, lesser hill myna, and brown-headed barbet were more dependent on fruits and they are highly abundant in forests and canopies with higher vegetation [33]. Additionally, they can be seen in home gardens in common. As Mee aba sevana premises are enriched with higher vegetation cover, they facilitate higher degree of habitations for those species. In Saiba ground, bird species such as Asian-paradise flycatcher, brown shrike, and house swift are feeding on insects and many larvae of insects (insectivore) and are abundant in open lands and urban areas in common [33]. Since Saiba ground contains different micro habitats to feed and rest for several insectivorous birds in an 
open area, findings of the study correlate with those of [33]. Carnivore birds species of cattle egret, shikra, greater coucal, house crow, and brown-breasted flycatcher were frequently recorded in Girls' Hostel complex as they are inhabiting closer to human habitations and feed on small mammals like mice and lizards. Higher disposal of food and household waste from hostels might be the main cause for the attraction of those birds in this area which might lead to increase in their population because, in some places, garbage accumulated plots support food sources for birds such as house crows.

Avifaunal species such as Asian-paradise flycatcher, black-rumped flameback, cattle egret, feral pigeon, house crow, pale-billed flowerpecker, small minivet, and whiterumped munia species were not significantly different in all the habitat types ( $p>0.05$, Kruskal-Wallis). The major reason for that may be they are widely available in ranges of habitat types. These bird species are common generalists in wide range of habitats. As most of these bird species can feed on various types of food sources, they show their presence as more common in home gardens and other human-modified landscapes [55]. Further, the Asian brown flycatcher was distributed in habitats of Saiba ground, medical center area, Mee amba sevana, Girls' Hostel complex, and English language training unit $(\mathrm{z}>0$, Kruskal-Wallis, Minitab 14). Asian brown flycatcher is less selective in its habitat. It seems partial to gardens and can be found even in densely populated localities where there are plenty of mature trees [55]. White-bellied drongo (Saiba ground, Thal weta premises, Mee amba sevana, Girls' Hostel complex, and English language training unit) was recorded as widely distributed within five habitats out of selected eight habitats ( $z>0$, Kruskal-Wallis, Minitab 14). White-bellied drongo appears in forest as well as suburban areas. In addition, it is common to low lands [55].

The second largest distribution was recorded by blackhooded oriole, blue-tailed bee-eater, cattle egret, feral pigeon, brown-headed barbet, oriental magpie robin, purple-rumped sunbird, red-vented bulbul, rose-ringed parakeet, and scalybreasted munia within four habitats out of eight selected habitats ( $\mathrm{z}>0$, Kruskal-Wallis, Minitab 14). Brown-headed barbet is famous as a garden bird readily found even in heavily built-up areas where higher vegetative cover is observed. It favors feeding on fruits. The birds excavate a nesting burrow, usually high up on an old exposed branch or tree trunk, out of reach of most predators [55]. Purple-rumped sunbird occurs in every garden in the suburbs, even in townships. They appear to have its resident pair [55]. Blue-tailed beeeater small parties will even take up residence in the tall trees. It takes up position on a high perch from which it sallies after aerial insects [55]. Moreover, scaly-breasted munia is more abundant in garden type habitats with vegetation. In addition rose-ringed parakeet also favors a habitat with vegetation cover and higher availability of fruiting plants $(\mathrm{z}$ $>0$, Kruskal-Wallis, Minitab 14). Black-hooded oriole is a bird which is very common and widespread, garden and forest bird. It can be seen in the tree-lined streets. However, due to its habits preference on tree tops, it is difficult to locate [55]. Built-up areas and other physical developments in modern urban landscapes increase the habitat isolation, fragmentation, and development density. These changes cause community composition and structure of associated avifaunal species to change from development-sensitive species to well adapted generalists that tolerate development stressors [55].

\section{Conclusion}

Birds are group of faunal species that are influenced by human attention. Therefore, some scenarios lead to reduction in insectivore birds and total birds' richness as a result of anthropogenic disturbances. In more human-modified urban land uses, less development-sensitive bird species can be seen while there are larger number of individuals of birds in recreational trails in forest and grassland ecosystems. Reduction and control of human-modified land uses within a greener area will facilitate habitat for sensitive species for rapid development activities with large scale disturbances. When constructions and developments are conducted, vegetation and plants are cleared and removed from the sites creating canopy gaps. This narrows down and separates habitat connectivity of habitats, making more sensitive species vulnerable and decreasing their population size. The study claimed that there was a variation of species diversity parameters among different land use patterns. Conservation and management efforts should be oriented toward protecting habitat and resources for developmentsensitive species, such as migrants, insectivores, and forest specialists, during the modification of available land uses. Most of birds inhabiting these areas are vulnerable to habitat degradation due to loopholes in existing legal protection. In addition, community knowledge enhancements also should be strengthened for a sustainable conservation of bird species while maintaining their ecological interactions. Future longterm studies are recommended covering migratory seasons and establishment of mimicable structures and landscapes during construction stages within the university premises.

\section{Data Availability}

The data used to support the findings of this study are available from the corresponding author upon request.

\section{Conflicts of Interest}

The authors declare that they have no conflicts of interest.

\section{Authors' Contributions}

P. A. B. G. Panagoda and H. W. G. A. S. Weerasinghe planned the study. B. K. A. Bellanthudawa, N. M. S. K. Nawalage, P. A. B. G. Panagoda, H. W. G. A. S. Weerasinghe, L. K. D. N. Tharaka, H. K. A. D. Silva, and D. M. S. N. Dissanayake participated in sampling sites selection and data collection. B. K. A. Bellanthudawa, N. M. S. K. Nawalage, S. Subanky, and M. S. J. Abeywickrama analyzed the data and created graphs. B. K. A. Bellanthudawa, N. M. S. K. Nawalage, and H. M. A. K. Handapangoda compiled the manuscript. 


\section{Acknowledgments}

Special thanks to Dr. (Mrs.) W. M. D. N. Wijeyaratne, Department of Zoology and Environmental Management, Faculty of Science, University of Kelaniya.

\section{References}

[1] G. T. Miller and S. E. Spoolman, Living in the Environment: Concepts, Connections and Solutions, 2014.

[2] F. Bibi and Z. Ali, "Measurement of diversity indices of avian communities at Taunsa Barrage Wildlife Sanctuary, Pakistan," Journal of Animal and Plant Sciences, vol. 23, no. 2, pp. 469-474, 2013.

[3] T. J. O’Connell, L. E. Jackson, and R. P. Brooks, "Bird guilds as indicators of ecological condition in the central Appalachians," Ecological Applications, vol. 10, no. 6, pp. 1706-1721, 2000.

[4] FOGSL, IBA Sri Lanka Project Report, Field Ornithology Group of Sri Lanka, University of Colombo, Colombo, Sri Lanka, 2003.

[5] G. J. Niemi and M. E. McDonald, "Application of ecological indicators," Annual Review of Ecology, Evolution and Systematics, vol. 35, no. 1, pp. 89-111, 2004.

[6] C. H. Schulze, M. Waltert, P. J. Kessler et al., "Biodiversity indicator groups of tropical landuse systems: comparing plants, birds, and insects," Ecological Applications, vol. 14, no. 5, pp. 1321-1333, 2004.

[7] J. A. Kushlan, "Colonial waterbirds as bioindicators of environmental change," Colonial Waterbirds, vol. 16, no. 2, p. 223, 1993.

[8] J. Wiens, S. A. Temple, and J. A. Wiens, Bird Populations and Environmental Changes: Can Birds Be Bio-Indicators?, 1989.

[9] N. Katayama, T. Osawa, T. Amano, and Y. Kusumoto, "Are both agricultural intensification and farmland abandonment threats to biodiversity? A test with bird communities in paddydominated landscapes," Agriculture, Ecosystems \& Environment, vol. 214, pp. 21-30, 2015.

[10] V. B. Subramanyam, "A preliminary assessment and diversity of birds in Ramagiri east and west forest, Ananthapuram District, Andhra Pradesh, India," International Journal of Zoology Studies, vol. 2, no. 4, pp. 21-28, 2017.

[11] B. L. Narayana, V. V. Rao, and J. Pandiyan, "Avifaunal assemblages in relation to different croplands/habitats of nalgonda district, andhra pradesh, India," International Journal of Life Sciences Biotechnology and Pharma Research, vol. 2, no. 3, pp. 212-224, 2013.

[12] M. C. Hansen, P. V. Potapov, R. Moore et al., "High-resolution global maps of 21st-century forest cover change," Science, vol. 342, no. 6160, pp. 850-853, 2013.

[13] P. Batáry, S. Fronczek, C. Normann, C. Scherber, and T. Tscharntke, "How do edge effect and tree species diversity change bird diversity and avian nest survival in Germany's largest deciduous forest?" Forest Ecology and Management, vol. 319, pp. 44-50, 2014.

[14] S. Pimm, P. Raven, A. Peterson, Ç. H. Şekercioğlu, and P. R. Ehrlich, "Human impacts on the rates of recent, present, and future bird extinctions," Proceedings of the National Acadamy of Sciences of the United States of America, vol. 103, no. 29, pp. 10941-10946, 2006.

[15] L. Fahrig and T. Rytwinski, "Effects of roads on animal abundance: an empirical review and synthesis," Ecology and Society, vol. 14 , no. $1,2009$.
[16] D. Palomino and L. Carrascal, “Threshold distances to nearby cities and roads influence the bird community of a mosaic landscape," Biological Conservation, vol. 140, no. 1-2, pp. 100109, 2007.

[17] J. D. Delgado García, J. R. Arévalo, and J. M. FernándezPalacios, "Road edge effect on the abundance of the lizard Gallotia galloti (Sauria: Lacertidae) in two Canary Islands forests," Biodiversity and Conservation, vol. 16, no. 10, pp. 29492963, 2007.

[18] E. H. Griffith, J. R. Sauer, and J. A. Royle, "Traffic effects on bird counts on North American breeding bird survey routes," The Auk, vol. 127, no. 2, pp. 387-393, 2010.

[19] R. Reijnen and R. Foppen, "The effects of car traffic on breeding bird populations in woodland. I. evidence of reduced habitat quality for willow warblers (Phylloscopus trochilus) breeding close to a highway," Journal of Applied Ecology, vol. 31, no. 1, pp. 85-94, 1994.

[20] P. Clergeau, J.-P. L. Savard, G. Mennechez, and G. Falardeau, "Bird abundance and diversity along an urban-rural gradient: a comparative study between two cities on different continents," Condor, vol. 100, no. 3, pp. 413-425, 1998.

[21] K. R. Crooks, A. V. Suarez, and D. T. Bolger, "Avian assemblages along a gradient of urbanization in a highly fragmented landscape," Biological Conservation, vol. 115, no. 3, pp. 451-462, 2004.

[22] P. Matson, "Special feature: the use of urban gradients in ecological studies," Ecology, vol. 71, no. 4, p. 1231, 1990.

[23] I. Laube, N. Breitbach, and K. Böhning-Gaese, "Avian diversity in a Kenyan agroecosystem: effects of habitat structure and proximity to forest," Journal of Ornithology, vol. 149, no. 2, pp. 181-191, 2008.

[24] J. Vandermeer, M. Van Noordwijk, J. Anderson, C. Ong, and I. Perfecto, "Global change and multi-species agroecosystems: concepts and issues," Agriculture, Ecosystems \& Environment, vol. 67, no. 1, pp. 1-22, 1998.

[25] N. Myers, R. A. Mittermeler, C. G. Mittermeler, G. A. B. da Fonseca, and J. Kent, "Biodiversity hotspots for conservation priorities," Nature, vol. 403, no. 6772, pp. 853-858, 2000.

[26] MOE, "The national red list 2012 of Sri Lanka," in Conservation Status of the Fauna and Flora, p. 467, Ministry of Environment, Colombo, Sri Lanka, 2012.

[27] D. K. Weerakoon and K. Gunawardena, "The taxonomy and conservation status of birds in Sri Lanka," in The National Red List, pp. 114-117, 2012.

[28] S. W. Kotagama, "Wildlife conservation and development of the south east dry zone," in The Southeast dry Zone of Sri Lanka. Colombo, Agrarian Research and Training Institute, 1993.

[29] J. Harrison and T. Worfolk, Field Guide to the Birds of Sri Lanka, Field Guide to the Birds of Sri Lanka, Oxford University Press, Oxford, UK, 1999.

[30] D. Warakogoda and U. Sirivardana, "The avifauna of Sri Lanka: an overview of the current status," Taprobanica, vol. 1, no. 1, pp. 28-35, 2011.

[31] J. Pithon, R. Moles, and J. O'Halloran, “The influence of coniferous afforestation on lowland farmland bird communities in Ireland: different seasons and landscape contexts," Landscape and Urban Planning, vol. 71, no. 2-4, pp. 91-103, 2005.

[32] S. Javed and R. Kaul, "Field methods for bird surveys," Bombay Natural History Society, 2002.

[33] D. Warakagoda, C. Inskipp, T. Inskipp, and R. Grimmett, Birds of Sri Lanka, Bloomsbury Publishing, 2016. 
[34] S. Kishoran, J. M. Harris, M. Vinobaba, and P. Vinobaba, "Bird diversity and threaten to their habitat in sathurukondan birding site in Batticaloa, Sri Lanka," Journal of Agricultural Science and Technology A, vol. 7, no. 2, pp. 123-128, 2017.

[35] C. H. Heip, P. M. Herman, and K. Soetaert, "Indices of diversity and evenness," Océanis, vol. 24, pp. 21-22, 1998.

[36] J. R. Karr and R. R. Roth, "Vegetation structure and avian diversity in several new world areas," The American Naturalist, vol. 105 , no. 945 , pp. $423-435,1971$.

[37] R. R. Roth, "Spatial heterogeneity and bird species diversity," Ecology, vol. 57, no. 4, pp. 773-782, 1976.

[38] J. D. Kottawa-Arachchi and R. N. Gamage, "Avifaunal diversity and bird community responses to man-made habitats in St. Coombs Tea Estate, Sri Lanka," Journal of Threatened Taxa, vol. 7, no. 2, pp. 6878-6890, 2015.

[39] A. Lewis and D. Pomeroy, A Bird Atlas of Kenya, CRC Press, Boca Raton, Fla, USA, 1989.

[40] D. J. Currie, "Energy and large-scale patterns of animal and plant species richness," The American Naturalist, vol. 137, no. 1, pp. 27-49, 1991.

[41] J. R. Turner, J. J. Lennon, and J. A. Lawrenson, "British bird species distributions and the energy theory," Nature, vol. 335, no. 6190, pp. 539-541, 1988.

[42] N. S. Alwis, P. Perera, and N. P. Dayawansa, "Response of tropical avifauna to visitor recreational disturbances: a case study from the Sinharaja World Heritage Forest, Sri Lanka," Avian Research, vol. 7, no. 1, pp. 1-13, 2016.

[43] R. E. Ricklefs, "Species richness and morphological diversity of passerine birds," Proceedings of the National Acadamy of Sciences of the United States of America, vol. 109, no. 36, pp. 14482-14487, 2012.

[44] R. Ricklefs, "Aspect diversity in moths revisited," The American Naturalist, vol. 173, no. 3, pp. 411-416, 2009.

[45] D. Tilman, Resource Competition and Community Structure, vol. 17, Princeton University Press, 1982.

[46] J. M. Chase and M. A. Leibold, Ecological Niches: Linking Classical and Contemporary Approaches, University of Chicago Press, 2003.

[47] P. D. Summers, G. M. Cunnington, and L. Fahrig, "Are the negative effects of roads on breeding birds caused by traffic noise?" Journal of Applied Ecology, vol. 48, no. 6, pp. 1527-1534, 2011.

[48] J. R. Barber, K. R. Crooks, and K. M. Fristrup, "The costs of chronic noise exposure for terrestrial organisms," Trends in Ecology \& Evolution, vol. 25, no. 3, pp. 180-189, 2010.

[49] J. Mason, C. Moorman, G. Hess, and K. Sinclair, "Designing suburban greenways to provide habitat for forest-breeding birds," Landscape and Urban Planning, vol. 80, no. 1-2, pp. 153164, 2007.

[50] S. R. Beissinger and D. R. Osborne, "Effects of urbanization on avian community organization," Condor, vol. 84, no. 1, pp. 7583, 1982.

[51] J. M. Fraterrigo and J. A. Wiens, "Bird communities of the Colorado Rocky Mountains along a gradient of exurban development," Landscape and Urban Planning, vol. 71, no. 2-4, pp. 263-275, 2005.

[52] R. Steven, C. Pickering, and J. Guy Castley, "A review of the impacts of nature based recreation on birds," Journal of Environmental Management, vol. 92, no. 10, pp. 2287-2294, 2011.

[53] K. R. Clarke and R. M. Warwick, Changes in Marine Communities: An Approach to Statistical Analysis and Interpretation, Primere, Plymouth, 2nd edition, 2001.
[54] P. Lee and J. T. Rotenberry, "Relationships between bird species and tree species assemblages in forested habitats of eastern North America," Journal of Biogeography, vol. 32, no. 7, pp. 11391150, 2005.

[55] C. H. Nilon, C. N. Long, and W. C. Zipperer, "Effects of wildland development on forest bird communities," Landscape and Urban Planning, vol. 32, no. 2, pp. 81-92, 1994. 


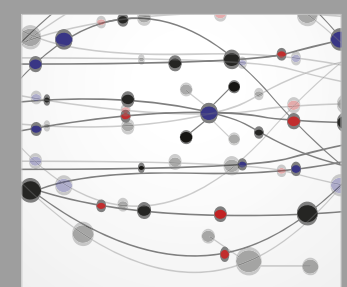

The Scientific World Journal
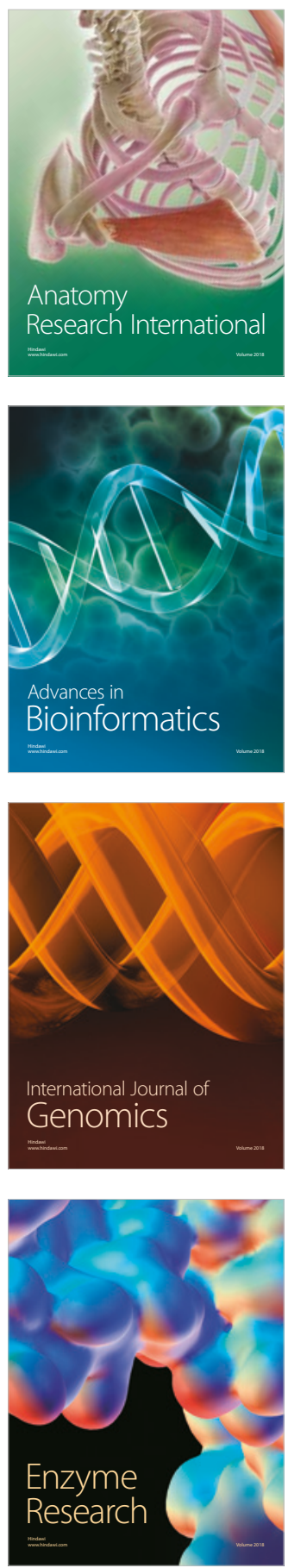
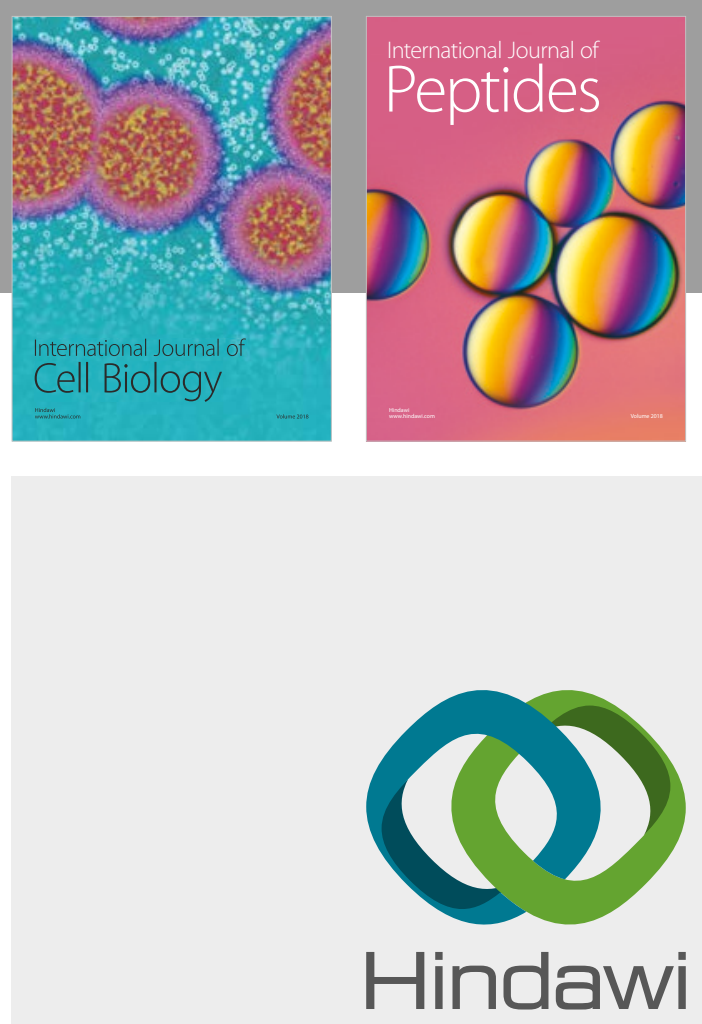

Submit your manuscripts at

www.hindawi.com
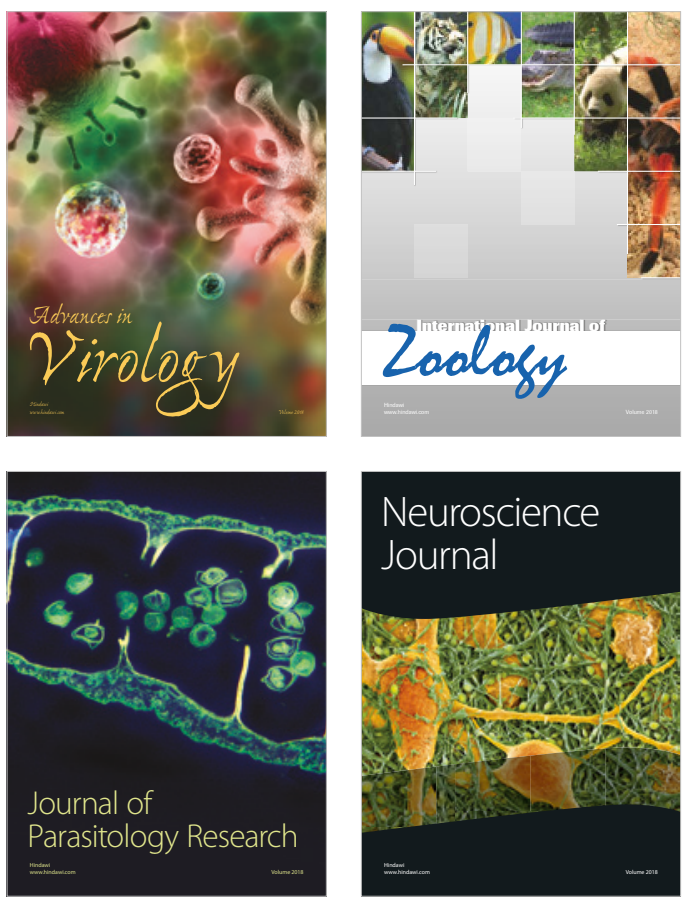
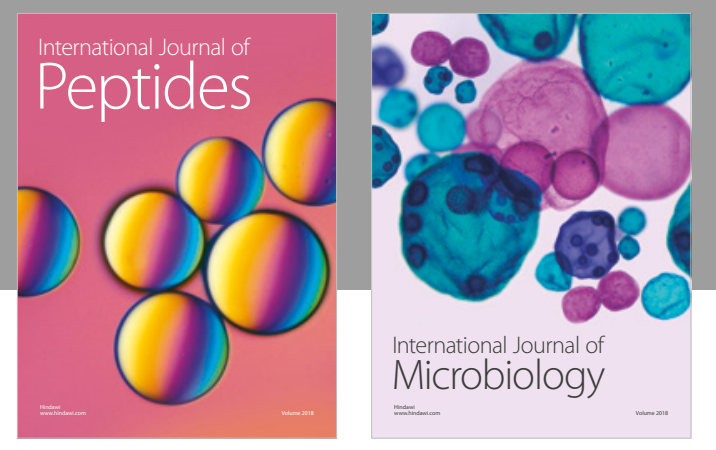

nternational Journal of Microbiology
Journal of
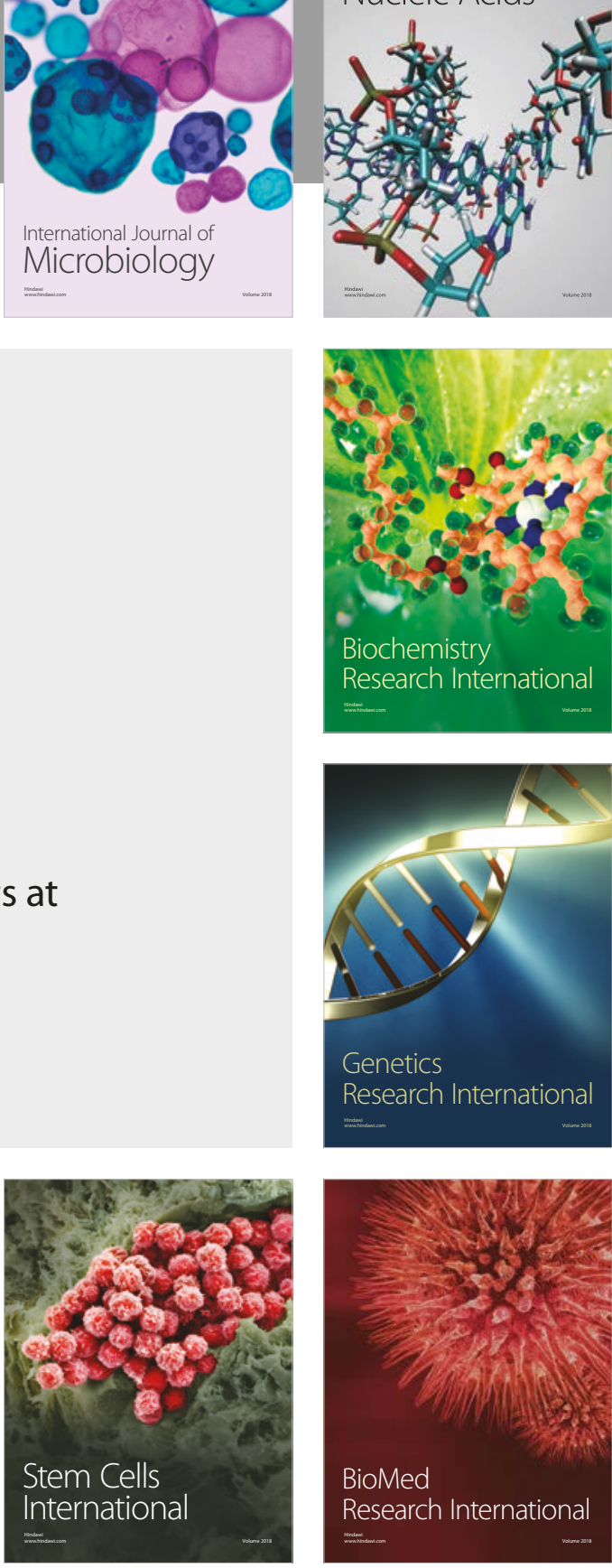
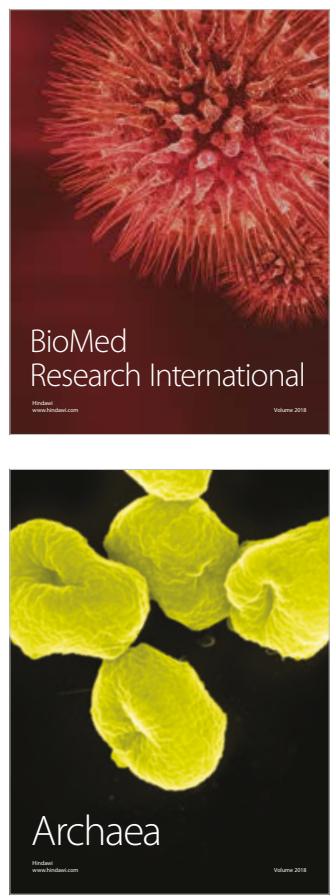